University of Baltimore Law ScholarWorks@University of Baltimore School of Law

All Faculty Scholarship

Faculty Scholarship

7-12-1994

\title{
Maryland's Adoption of a Code of Evidence
}

Lynn McLain

University of Baltimore, lmclain@ubalt.edu

Follow this and additional works at: http://scholarworks.law.ubalt.edu/all_fac

Part of the Evidence Commons

\section{Recommended Citation}

Lynn McLain, Maryland's Adoption of a Code of Evidence, (1994).

Available at: http://scholarworks.law.ubalt.edu/all_fac/930

This Article is brought to you for free and open access by the Faculty Scholarship at ScholarWorks@University of Baltimore School of Law. It has been accepted for inclusion in All Faculty Scholarship by an authorized administrator of ScholarWorks@University of Baltimore School of Law. For more information, please contact snolan@ubalt.edu. 


\title{
Maryland's Adoption of a Code of Evidence
}

\author{
Lynn McLain
}

\begin{abstract}
"Consider your verdict," the king said to the jury.
"Not yet, not yet!" the Rabbit hastily interrupted. "There's a great deal to come before that!"

- Lewis Carroll, Alice's Adventures in wonderland
\end{abstract}

For the first time in its history, Maryland has a code of evidence -- Title 5 of the Maryland Rules -- to govern the admission of evidence at trial. Title 5, like the Federal Rules of Evidence, is in a number of ways more liberal as to admissibility (and, in others, less liberal) than was the common law.

With the Court of Appeals' adoption of Title 5, effective July 1, 1994, Maryland became the thirty-eighth state to adopt a code of evidence derived from the Federal Rules of Evidence, which became effective nineteen years earlier, July 1, 1975. Preliminary work was done on Title 5 by the Rodowsky Subcommittee of the court of Appeals Rules Committee in 1976 and 1977, but the Court of Appeals decided that it was premature to proceed with codification, until there had been significant experience in the federal courts with the federal rules.

In 1988, the court authorized the Rules Committee to begin anew proposing an evidence codification. The Chair of the Committee, Chief Judge Alan M. Wilner of the Court of Special Appeals, assured the members of the Court of Appeals that the Rules 
Committee would not blithely propose Maryland's adoption of the federal rules, but would attempt to evaluate the applicable Maryland law, the federal rules and the cases construing them, and the laws of all other states having evidentiary codes, and draft proposed rules which it thought best for Maryland. Many of the choices turned on policy determinations, which were made ultimately by the Court of Appeals, after public hearings and other opportunities for public comment.

The result is a code of evidence that is organized and numbered almost identically to the Federal Rules of Evidence and the Uniform Rules of Evidence, so as to facilitate the location, as persuasive authority, of cases in federal and other state jurisdictions construing similar rules. The rule numbers generally are the same as those of Federal Rules Evidence, except that the prefix "5-" - is added to the Maryland Rules." Also, because the Maryland Rules do not address evidentiary privileges, there is no counterpart in Title 5 to Fed. R. Evid. 501. Evidentiary privileges in Maryland continue to be governed by constitutional provisions, $\mathrm{myriad}$ of statutes, and by common law.

1. There are a few exceptions. The subject matter addressed in Fed. R. Evid. 801 (d) (1) and $803(5)$ is found in Md. Rule 5-802.1, which lists five hearsay exceptions for certain out-of-court statements of witnesses who are testifying at the trial. "Admissions of party opponents," which are addressed in Fed. R. Evid. $801(d)(2)$, are governed by Md. Rule 5-803(a). The hearsay exceptions that are listed in Fed. R. Evid. 803 are found in Md. Rule 5-803(b). Md. Rule 5-616 has no corollary in the federal rules. 
Nor is the pre-Title 5 Maryland law concerning the admissibility of evidence in general overruled, unless it is inconsistent with the Rules in Title 5. See Md. Rule 1-201(c). Because Title 5 is to a large extent a codification of the Maryland common law, those Maryland cases fleshing out the now codified common law rules will continue to inform as to the meaning of the Rules.

The heart of Title 5 - its alpha and its omega -- is contained in Rules 5-401 through 5-403. Rules 5-401 and 5-402 codify the fundamental requirement at common law that, in order to be admissible, evidence must be relevant to a fact that is of legal significance to the case. Rule 5-402 provides that all relevant evidence is admissible, except as otherwise provided "by constitution, statutes, or these rules, or by decisional law not inconsistent with these rules." For example, the federal and state constitutions would exclude evidence obtained in violation of the privilege against self-incrimination; the Maryland "dead man's statute," section 9-116 of the Courts and Judicial Proceedings article of the Code, would exclude certain relevant evidence; Rule 5-411 generally excludes proof of insurance when offered on the question of liability; and case law provides that pleas of nolo contendere are inadmissible as statements of a party opponent, unless otherwise provided by rule (see the BV rules). Agnew V. State, 51 Md. App. 614, 651-53,446 A.2d 425, 445-46, cert. denied, 294 Md. 441 (1982). 
Rule 5-403 codifies the court's ability at common law to exclude even relevant evidence that is not excluded by more specific Rules, if the court finds that the risks of unfair prejudice, confusion or distraction of the fact-finder, or undue consumption of time substantially outweigh the proffered evidence's probative value. Again the pre-Title 5 case law stands, as a basis for interpreting the Rule. See, e.g., Briggeman V. Albert, 322 Md. 133, 138, 586 A.2d 15, 17 (1991); State V. Watson, 321 Md. 47, 57, 580 A2d 1067, $1072(1990)$.

A number of the Maryland Rules reject the federal practice in favor of Maryland's traditional approach. For example, under Rule 5-103 (a) (1) counsel need not state the ground of objection, unless the court requests the ground. Rule 5-301 codifies Maryland's treatment of burden-of-production-of-the-evidence-shifting presumptions in civil cases set forth in Grier V. Rosenberg, 213 Md. 248, 131 A.2d 737 (1957), which is somewhat of a middle ground between Fed. R. Evid. 301 and the Thayer-Wigmore "bursting bubble" and Unif. R. Evid. 301 which follows the Morgan approach.

Rule 5-802.1(a) builds on the Court of Appeals' revolutionary decision in Nance V. State, 331 Md. 549, 629 A.2d 633 (1993), and follows Hawaii's rule, permitting broader substantive use of a witness's prior inconsistent statements (if written and signed; or if stenographically or electionically recorded; or if made under oath at deposition, trial or in a hearing or another proceeding, 
including a grand jury proceeding) than either was possible under the common law or is possible under the Federal Rules of Evidence.

In the interest of judicial economy, Rule 5-902(a) (11) follows a new provision in the Uniform Rules of Evidence that has no corollary in the Federal Rules, but is derived in part from 18 U.S.C. \$ 3505. The Maryland Rule permits self-authentication of certified copies of business records, so as to avoid having to call a records custodian. Cf. Md. Rules 2-510 (g) and 3-510(g) (hospital records).

Md. Rule 5-616, in an attempt to further one of the goals of codification, accessibility of the law, catalogues the methods of impeachment and rehabilitation of witnesses, as well as when extrinsic evidence of such matters is permitted. The federal rules contain no corollary to Rule 5-616.

A few of the Rules speak to issues that are unaddressed by the Federal Rules of Evidence and also change Maryland law. For example, Rule 5-615(c) permits a court in its discretion to allow a child witness's parents or another support person to remain in court during the child's testimony, despite a sequestration order. Rule 5-802.I (d) broadens the Maryland common law hearsay exception for prompt complaints of rape, so as to include prompt complaints of sexual assault, in general, and is not restricted to criminal cases. 
The language of some of the Maryland Rules resolves issues as to which the federal rules are inexplicit but the federal cases are relatively clear. For instance, Rule 5-408 provides that evidence of settlement negotiations in civil cases that would be protected in the civil case also will be inadmissible in criminal proceedings concerning the same subject matter. Other Maryland Rules resolve issues on which the federal cases are split. For example, Rule 5803 (b) (3) provides that a declarant's statement of intent is admissible only to prove the declarant's (and not another's) subsequent act.

Rules in Title 5 that overrule Maryland cases in favor of the federal approach include, for instance, Rule 5-407, which follows the federal rule's policy of general exclusion of evidence of subsequent remedial measures, rather than Wilson V. Morris, 317 Md. 284, 563 A.2d 392 (1989); Rules 5-803(b) (16) and (18), which adopt hearsay exceptions for trustworthy ancient documents and for learned treatises; and Rules 5-803(b)24 and 5-804(b) (5), which adopt the safety valve of residual hearsay exceptions to permit, "[u]nder exceptional circumstances," growth and development of the hearsay doctrine when appropriate.

The Court of Appeals decided to leave resolution of some issues to its construction of the applicable Rule in case law, after briefing and argument, rather than in the rule-making process. For example, the court reserved judgment on whether its 
adoption of Rule 5-702 would lead to its following the more liberal approach to admission of expert testimony outlined in Daubert $v$. Merrill-Dow Pharmaceuticals, Inc., _U.S. __, 113 S. Ct. 2786, 125 L.Ed 2d 469 (1993), rather than Maryland's Frye-Reed test. See, e.g., Reed V. State, 283 Md. 374, 291 A.2d 364 (1978). It also declined to adopt language making Rule 5-407 explicitly apply (or not) to products liability cases, an issue on which the federal circuits are divided.

Although of course there are differences of opinion as to a number of the particular choices made in the Rules, the response of the bench and bar to date has been overwhelmingly positive to the act of codification. Those of us who participated in the project can only hope that they continue to feel that way, as they conduct trials under the Rules. 